\title{
AUDITORY PROCESSING AND APHASIA: A SYSTEMATIC REVIEW
}

\section{Processamento auditivo e afasia: uma revisão sistemática}

\author{
Maria da Soledade Rolim do Nascimento(1), Lilian Ferreira Muniz ${ }^{(2)}$, Maria Lúcia Gurgel da Costa ${ }^{(3)}$
}

\begin{abstract}
The auditory processing evaluation is an audiological procedure that provides important information related to the process of understanding linguistic material. Aiming to investigate the research about the interface Auditory Processing - Aphasia a systematic review was made with reference to the following descriptors and their correlates in the English language: Aphasia, Dichotic, Monotic, Auditory Processing and Auditory Abilities. The search was conducted in the intersection format with connective "and". The five studies found in this review differ in many aspects such as lesion location, change of hemispheric dominance for language, presence of a left ear advantage in aphasia, relationship between auditory abilities and language and auditory extinction. These papers suggest that the two theoretical approaches on auditory processing and aphasia: localizationist and distributive arguments. Most of papers (three) agree with the distributive argument.
\end{abstract}

KEYWORDS: Aphasia; Hearing; Speech, Language and Hearing Sciences

\section{INTRODUCTION}

Aphasia is a language disturbance, as a general rule is a consequence of structural brain injury, such as those caused by stroke, traumatic brain injury, brain tumor among other ${ }^{1}$.

Aphasia causes language disintegration, this disintegration may affect the comprehension and expression of oral verbal symbols and/or written symbols, harming the individual interaction with own environment ${ }^{2}$. Language disorganization in aphasic individuals may occur in different types of perceptual input, such as: visual, expressive, oral, graphic and auditory.

Auditory is an important requirement for the efficient use of language, both in understanding linguistic material received as in the expressive

\footnotetext{
(1) Federal University of Pernambuco, Recife, PE, Brazil.

(2) Speech Language and Hearing Science Department, Federal University of Pernambuco - UFPE, Recife, PE, Brazil;

(3) Speech Language and Hearing Science Department, Federal University of Pernambuco - UFPE, Recife, PE, Brazil;

Fomento: Conselho Nacional de Desenvolvimento Científico e Tecnológico - CNPq. Processo n: 134049/2010-1

Conflict of interest: non-existent
}

language monitoring. Specific limitations imposed by aphasia sometimes prevent or make slower operations on language resources. Some examples of specific limitations are difficulties in the production of articulatory gestures, difficulty with lexical access, problems with the syntactic structure, linguistic or linguistic cognitive difficulties - noticeable in cases of posterior aphasias ${ }^{3}$.

Auditory processing (AP) is the set of skills necessary to process the sound signal, which also involves the peripheral auditory behavior ${ }^{4}$. Thus, the physiology of hearing is intrinsically related to auditory abilities (auditory abilities are a behavior that a person demonstrates when process information received through the auditory modality). Location and sound lateralization, auditory discrimination, auditory recognition, temporal aspects of hearing (resolution, masking, integration and temporal ordering) and auditory performance on a competitive acoustic signal are some of behavioral phenomena elicited by the processing of the sound stimulus ${ }^{5}$.

An effective communicative performance begins with the detection of the auditory stimulus (in the cochlea), occurring linguistic analysis of information in the cerebral cortex. Failures at some point this fast and complex path can bring impairments in 
communication, language is a means of integration and the loss of this instrument can be a source of isolation and loneliness for the person with aphasia ${ }^{2}$.

Considering the aforementioned, it is possible that changes in auditory processing (primary or secondary to aphasia) can bring negative impacts to the integration of the person with aphasia within a society that relies increasingly on the precepts of rapid and objective communication.

Thus, the objective of this research is to investigate the research addressing the interface Auditory processing - Aphasia through a systematic review.

\section{METHODS}

This is a quantitative, cross-sectional and retrospective study, a systematic review. This study was developed by three researchers, initially, two of them looked for data through an independent and blind way. The third research was appointed as reviewer (this reviewer was consulted in doubt moments) with purpose to establish an idea agreement. The systematic review was made in accordance with Cochrane Collaboration ${ }^{6}$ and Sampaio; Mancini ${ }^{7}$, adopting as reference these descriptors and their correlates in the Portuguese: aphasia, dichotic, monotic, auditory processing and auditory abilities. The search was conducted in the intersection format with connective "and".

Articles were included whose sample was composed of adult individuals with aphasia who had done some kind of auditory processing. Excluded texts were those who didn't fit the characteristics before-mentioned, beyond previous papers to 1980 , studies that compared subjects with different pathologies and patients with aphasia in the same experimental group and reviews.
The search was conducted in the period between August and November 2011. Descriptors were selected in accordance with DeCS list (Descriptors terms of health Bireme) and were also used keywords that had higher sensitivity for prospecting studies. Through the DeCS list the selected descriptor was aphasia (afasia), the other descriptors were chosen: Dichotic (Dicótico), Monotic (Monótico), auditory processing (processamento auditivo) and auditory abilities (habilidades auditivas).

The database consulted for this review were Pubmed (US National Library of Medicine), Scielo (Scientific Eletronic Library Online), LILACS (Literatura Latino-Americana e do Caribe em Ciências da Saúde), Scirus - for scientific information only and Journal Portal Capes.

According to the criteria for inclusion and exclusion, 2201 citations were identified in electronic databases, with 2154 citations excluded based on title and abstract, leaving 47 articles. Of these, one article was located in SciELO portal and repeated in LILACS portal and 24 articles found in Pubmed were repeated in Scirus portal, so getting 22 articles for analysis. Two more articles were located through references, however, one of them aggregated in the same experimental group patients with aphasia and individuals with lesions in the central nervous system (CNS), with the same excluded from the sample. A total of 23 articles were left for analysis.

The methodological quality of studies was assessed based on the PEDro scale (Physiotherapy Evidence Database - Figure 1), this scale commonly used in rehabilitation (Physiotherapy, Occupational Therapy and others) and used in experimental studies $^{7}$. Adopted the minimum score of 05 points for inclusion of papers in this present review, according to the methodology used by Coury et $a{ }^{\beta}$. 
1. Eligibility criteria were specified no ( ) yes ( ) where:

2. Subjects were randomly allocated to groups (in a crossover study, subjects were randomly allocated an order in which treatments were received)

no ( ) yes ( ) where:

3. Allocation was concealed no ( ) yes ( ) where:

4. The groups were similar at baseline regarding the most important prognostic indicators no ( ) yes ( ) where:

5. There was blinding of all subjects no ( ) yes ( ) where:

6. There was blinding of all therapists who administered the therapy no ( ) yes ( ) where:

7. There was blinding of all assessors who measured at least one key outcome no ( ) yes ( ) where:

8. Measures of at least one key outcome were obtained from more than $85 \%$ of the subjects initially allocated to groups no ( ) yes ( ) where:

9. All subjects for whom outcome measures were available received the treatment or control condition as allocated or, where this was not the case, data for at least one key outcome was analyzed by "intention to treat" no ( ) yes ( ) where:

10. The results of between-group statistical comparisons are reported for at least one key outcome no ( ) yes ( ) where:

11. The study provides both point measures and measures of variability for at least one key outcome no ( ) yes ( ) where:

Criterion number 1 is not scored, maximum score $=10$ points

Available in: https://translate.google.com.br/\#pt/en/dispon\%C3\%ADvel\%20em

Figure 1 - Model of the PEDro Scale - English

Table 1 - Analysis of the methodological quality of the articles according to the PEDro Scale

\begin{tabular}{ccc}
\hline $\begin{array}{c}\text { Articles with scores } \\
\text { up to } \mathbf{0 3} \text { points }\end{array}$ & $\begin{array}{c}\text { Articles with score } \\
\text { between } \mathbf{0 - 2}\end{array}$ & $\begin{array}{c}\text { Items that most impacted } \\
\text { in the exclusion of articles }\end{array}$ \\
\hline & & $\begin{array}{c}\text { Criterion } 5-7 \text { (be blind to the study) } \\
\text { Criterion } 3 \text { (secret allocation) }\end{array}$ \\
& $12(66,7 \%)$ & $\begin{array}{c}\text { Criterion } 10 \text { (inter-group statistical comparison) } \\
\text { Criterion } 11 \text { (measures of accuracy and variability) }\end{array}$ \\
\hline
\end{tabular}

Eighteen articles didn't meet the minimum criteria of methodological PEDro scale. From these works, six (33.3\%) achieved a score of 03 on that scale and twelve $(66.7 \%)$ had a score between zero and two. The items that most impacted for the non-inclusion of these eighteen studies were the criteria 5-7, 3, 10 and 11 of the PEDro scale. 


\section{REVIEW OF LITERATURE}

The articles written by Niccum ${ }^{9}$, Niccum et al ${ }^{10}$ and Niccum et $a^{11}$ followed a common methodological approach because the population of the first study stimulated the production of the following two texts: Niccum et $a{ }^{10}$ and Niccum et $a{ }^{11}$. The subjects were the same in these three surveys and consisted of 54 patients with aphasia, right-handed, 15 women and 39 men who had suffered a single ischemic stroke in the left cerebral hemisphere. Volunteers of the research were fluent English speakers, with an average education of eight years.

Articles above mentioned follow the guiding hypothesis that recovery of language in these patients is mediated by a progressive change in dominance for language (advantage), which migrates from the left hemisphere to the right in the first six months after the insult, this hypothesis grounded in the model dichotic perception proposed by Kimura, where the contra-lateral pathway dominates over the ipsilateral pathway, explained as follows: when the verbal test stimulus is presented to the right ear via the contralateral side, comes directly to the left hemisphere. In the opposite situation, the stimulus presented to the left ear goes to the right hemisphere through the corpus callosum and reaches the left hemisphere, which will be analyzed ${ }^{14}$.

For conducting their studies, Niccum ${ }^{9}$, Niccum et $a l^{10}$, Niccum et $a l^{11}$ have used the test of digits (TD) in the forms of monotic and dichotic presentation with the population studied. In these three articles the subjects should present hearing thresholds up to $40 \mathrm{~dB} \mathrm{HL}$ in the testing of the frequencies 500 , $1000,2000 \mathrm{~Hz}$ (speech area), in a situation of pure tone audiometry. The pure tone thresholds were obtained in the first month after stroke and after six months, the volunteers were retested.

The probable left ear advantage (Left Ear Advantage - LEA) in individuals with aphasia was investigated in the studies by Niccum $^{9}$, Niccum et $a l^{10}$, Niccum et $a /^{11}$. Niccum ${ }^{9}$ reported that only four $(15 \%)$ of the 27 patients included in the linear trend analysis of dichotic digits test showed patterns of LEA, a situation that has been described in the research of Bamiou et $a^{/ 15}$. Finally, the author $\left(\right.$ Niccum $^{9}$ ) inferred that the longitudinal data from your search did not provide consistent evidence of a change of cerebral hemispheric dominance for language in the first six months after the occurrence of a stroke. It questioned whether the advantages of ears (EA's - Ear advantages) observed in one month should be interpreted as an effect of injury or a dominance effect.

The shift in hemispheric dominance for language (dominance of the right hemisphere) was also investigated in the work of Niccum; Rubens ${ }^{16}$ where individuals with aphasia showed a recovery of lefthemisphere dominance, in opposition to the proposition of the aforementioned studies Kimura. Studies like these, that aimed to analyze the hemispheric dominance for language in the tables of aphasia, suggest a perspective localizationist approach to the discussion of auditory processing and language comprehension in these particular subjects (people with aphasia).

Niccum et $a /^{10}$ observed a tendency of the group of patients with extensive lesions in the left hemisphere to submit lower scores in the right ear and a larger left ear advantage (Left Ear Advantage - LEA), however, these subjects were more likely to develop damage in the primary auditory system.

Niccum et a/11 reported in their study that patients with the greatest impairment in expressive language and memory showed no greater tendency to LEA during the course of recovery than individuals with less extensive lesions.

Moreover, Niccum ${ }^{9}$ reported the incidence of hearing loss in the higher frequencies in the population studied, which is justified by the large proportion of individuals above 50 years of age who participated in this survey. This fact was taken into account when interpreting the findings, where no apparent association was found between the results in pure tone audiometry and performance of these people in dichotic and monotic tests.

The relationship between the extent of lesions in the cerebral hemispheres and the standard of performance of people with aphasia in the test of digits was studied by Niccum et $\mathrm{al}^{10}$. The lesions were studied by computed tomography (CT), performed five months after the stroke. Examinations of the patients were obtained using a Siemens CT scanner of high resolution, for defining the extent of injury score was assigned as follows:

- $0=$ No obvious damage;

- 1 = Questioning of a minor damage;

- 2 = Damage is present, but it reaches less than $50 \%$ of the area;

- 3 = Extensive damage, but not complete;

- $4=$ Total damage or almost total in the area;

Patients with scores 0 or 1 were allocated to group which existed in no or minimal damage from a particular region, while those with higher scores were part of another group with definite presence of injury. The criteria for defining normal performance were defined separately by means of a control group of adults between 35-75 years old, right-handed, with no history of stroke or other significant neurological changes. 
Niccum et a/10 used a careful analysis to assess the effect of the presence of contralateral ear effect, with the goal of determining whether the results of the dichotic digits test could perform better separation of patients with or without significant damage of Heschl's gyrus. Data collection was obtained in the first and sixth month after stroke.

In the first month after stroke, the data indicated that the scores of the right ear of the test of digits (TD) were most associated with damage to the superior and posterior regions of the temporal lobe (21 of 28 patients classified with this type of injury). Conversely, in the sixth month after the insult, these same results of TD were the most strongly associated with lesions involving the Heschl's gyrus (31 of 41 patients classified with this type of injury).

Thus, Niccum et a $/^{10}$ concluded that the scores obtained in the right ear, through the dichotic test of digits, showed a very close relation with the absence or presence of significant lesions in the Heschl's gyrus. However, this result may have been accentuated by the time course of injury $(71 \%$ of patients showed this correlation in the first month after the insult and $85 \%$ at six months).

In the study by Niccum et a ${ }^{11}$ dichotic listening tests were applied in people with aphasia, for which the evaluation of the ability of expressive language and memory were also possible. Tests of language and memory were realized applying a score of overall severity of aphasia, a combined of the following tests: Word Comprehension Test, Token Test and Receptive Syntax Test and other assessment battery with NCCEA, Boston Naming Test and Communicative Capacity tests.

The results of dichotic listening tests and the severity of aphasia were obtained in the first and sixth month after stroke, for comparisons. Positive relations were observed for measures of dominance ears (Ear advantages). According to the initial hypothesis of this study, the greater was the left ear advantage (LEA), the score would be lower in language tests, since there would be a possible dominance of the right hemisphere. Indeed, the extent of injury of the subjects was significantly related to the severity of deficits in language. However, relations between the extensions of the lesions and the results of ear dominance were less conclusive.

Based on the results of language tests, subjects were divided into two groups: fluent and non-fluent. The findings related to the scores on the dichotic digits test indicated that these patients didn't differ regarding the performance obtained in this task. However, fluent volunteers tended to have higher rates in dichotic tests with words.
The authors concluded in this study that the dichotic listening tests are those that most closely reflect the absence or presence of damage in the central auditory system; however these predictions are not always reliable. Furthermore, the findings of this research don't support the following hypotheses: a) most affected patients are initially more dependent on the right hemisphere (change of hemispheric dominance for language) b) patients with major deficits demonstrate transfer the language dominance for left hemisphere during the course of their recovery $c$ ) the degree of recovery achieved is related to the extent (volume) of the right hemisphere.

Ortiz and Peroni ${ }^{12}$ evaluated in their study the auditory abilities of figure-ground and selective attention in 20 patients with aphasia, all with a history of ischemic stroke. The M1-Alpha test language has been applied previously in these volunteers and only those who had mild oral comprehension disorders were included in the study. The stages of evaluation of this study comprised the realization of pure tone audiometry (frequencies of 500, 1000 and $2000 \mathrm{~Hz}$ ), speech reception threshold (SRT), acoustic impedance measurements and the PSI test - Pediatric Sentence Intelligibility.

In the PSI test, the stimuli were applied in dichotic listening situation (competitive contralateral message - CCM at presentation level $0 \mathrm{~dB} \mathrm{HL}$ and -40 $\mathrm{dB} H \mathrm{HL}$ ) and monotic listening (ipsilateral competitive message - ICC at level presentation OdBNA and -10 $\mathrm{dB} H L$ ) using ten phrases that should be identified by means of the corresponding figures. The results were compared with a control group.

The analysis of the findings obtained noticed that in the situation of CCM to $-40 \mathrm{~dB} H \mathrm{HL}$ was possible to observe a statistically significant difference between the results of patients with aphasia and the control group. Aphasic individuals, when exposed to a situation of competitive message, couldn't identify longer the sentences. In the situation of ICC, the group of subjects with aphasia had worse performance on the left and right ear in situations of presentation OdBNA and $-10 \mathrm{~dB} H \mathrm{HL}$, respectively.

Thus, from the results obtained, the authors were able to conclude that patients with aphasia, with a slight disorder of understanding demonstrated difficulties in performing tasks that require the abilities of figure-ground and selective attention to verbal sounds in listening to competing message. The findings indicate a loss of auditory comprehension in a situation of sound competition in these patients, thus reinforcing the importance of conducting assessments capable of providing data on the understanding of these subjects in more 
contextualized situations with the dynamics of communication in everyday life.

Shisler ${ }^{13}$ aimed, in her research, determine if auditory extinction is present in individuals with aphasia, and if so, whether this extinction is due to a defect in integration (binding). Extinction is generally defined as a failure to respond to a contralesional target during simultaneous presentations of stimuli for both hemispheres - left and right or when both stimuli are presented on the same side. Already integration (binding) refers to the union of sensory information (identity and location) into a whole, resulting in the perception of an object or event ${ }^{17}$.

Shisler's study was conducted in six individuals with aphasia, aged between 42 and 74 years and six healthy adult subjects, matched for age. Two different experiments were conducted, in which auditory stimuli consisting of male and female voices speaking the letters "T" or "O" were systematically varied to investigate if the integrate sensory information (binding) contributes to the occurrence of the phenomenon of extinction.

The group with aphasia included six subjects, monolingual speakers of British English, selected at Northeast Georgia Medical Center and Athens Stroke Club. The selection criteria for the participants included: a) identification of aphasia through the application of a validated test $b$ ) understanding of complex commands $\mathrm{c}$ ) hearing of simple stimuli ("T" or "O") to $80 \mathrm{~dB}$ SPL bilaterally presented from a computer in free field - called DSS (Double Simultaneous Stimulation) and d) the severity rating of 3 or 4 on the Boston Diagnostic Aphasia Exam Short. In addition to the above factors, were also considered as exclusion criteria the presence of neurological disorders such as stroke, Parkinson's disease, Alzheimer's disease, psychiatric disorders, learning disabilities, seizures and attention deficit disorders.

Auditory stimuli for the experiment were produced by digitizing the speech of a man and a woman, each spoke the letters " $\mathrm{T}$ " and "O", at an interval of $300 \mathrm{~ms}$, using the software Sound Blaster (Creative Computing Inc.) in 24 bits.

Experiment number 1 consisted of the application of the following tasks: identification of letters and identification of sex. Participants were asked to report the location of the stimulus (left or right) and identify each stimulus or report if they haven't heard anything. Therefore, when the task was to identify the letter (for example, the "T" was presented to the left and the "O" was shown at right, the volunteer answered "T" Left / "O" Right). The volunteers were allowed to respond verbally or point to the location of the letter, a visual representation of "T" or "O".
Experiment number 2 used the same conditions of stimulus presentation, but using numbers. Participants needed simply count the number of stimuli that were presented (one or two stimuli were possible). For this task, the error of omission was considered in two situations: a) identification of only one of two stimuli, b) identification of no stimulus;

The findings of the Shisler's study ${ }^{13}$ showed that most auditory extinction was found in the Experiment 1 , in the group of people with aphasia (all subjects showed extinction). In the same group, auditory extinction was more common in tasks that required the integration (binding) and decreased significantly in the non-integrative activities (Experiment 2). In the non-integrative task, the experimental group (with aphasia) showed a decrease of omission errors, suggesting that the ability of integration can influence performance in listening and also be an important resource for the rehabilitation of these patients.

Ortiz; Peroni ${ }^{12}$ and Shisler ${ }^{13}$ studies explorated the interface auditory processing and aphasia through other aspects, such as auditory abilities, auditory extinction and integration (binding). Considering that language can't be divorced from listening, these studies can be analyzed in an argument supported by the precepts of distributive theory, corroborated by the work of Nicolelis ${ }^{18}$ and Lebedev et $a^{19}$. The distributionist argument explains brain function or behavior from the premise that the human brain prefers to accomplish all your tasks through the collective work of large populations of neurons distributed across multiple brain regions, able to participate in the genesis of multiple functions simultaneously.

Still in the path of distributive theory, the occurrence of important relationships between language abilities and left brain areas compromised by vascular injury may vary, not being faithful to local traditionally expected to submit commitments due to injury ${ }^{20}$. These findings reinforce the importance of studies that involving auditory processing and language in the frameworks of aphasia, for better understanding of communication disorders in these patients.

Finally, the characteristics of each study selected in this review are summarized in Table 2.

\section{CONCLUSION}

The probable existence of a left ear advantage in patients with aphasia and a shift in hemispheric dominance for language (dominance of the right hemisphere) were not points of agreement in the evaluated studies; such events have been previously described and supported by classical 
research on auditory processing, these being the stimulator hypotheses for the major studies in this area of knowledge. Thus, it is inferred that the localizationist prospected observed in these studies does not address holistically the discussion of auditory processing and language comprehension in aphasic people.

However, papers dealing with the interface auditory processing and aphasia through other ways, such as auditory abilities, auditory extinction and integration, seemed to think the language should not be dissociated from auditory comprehension, this assertion can be supported by principles of the distributionist theory of cortical function.

Thus, given the above, it appears that auditory processing is crucial for language competence, therefore deepen the knowledge of their interfaces with language through new studies may be of great value to the rehabilitation of patients with communication disorders, especially those with aphasia.

Table 2 - Comparative box with the studies of Niccum (1986), Niccum et al, 1986 (A), Niccum et al, 1986 (B), Ortiz and Peroni (2008) and Shisler (2005)

\begin{tabular}{|c|c|c|c|c|}
\hline Article & Population & Objectives & $\begin{array}{l}\text { Method } \\
\text { (data collection) }\end{array}$ & Conclusions \\
\hline Niccum (1886) & $\begin{array}{l}54 \text { patients with } \\
\text { aphasia }\end{array}$ & $\begin{array}{l}\text { Check if there is } \\
\text { change of hemispheric } \\
\text { dominance in the period } \\
\text { up to } 6 \text { months after } \\
\text { stroke }\end{array}$ & $\begin{array}{l}\text { Audiological evaluation } \\
\text { of freq. } 500,1000 \text { and } \\
2000 \mathrm{~Hz} \text {, test of digits } \\
\text { and words in monotic or } \\
\text { dichotic mode; }\end{array}$ & $\begin{array}{l}\text { There was no consistent } \\
\text { evidence of change of } \\
\text { hemispheric dominance } \\
\text { to the right hemisphere } \\
\text { after stroke. }\end{array}$ \\
\hline $\begin{array}{l}\text { Niccum et al, } \\
1986(A)\end{array}$ & $\begin{array}{l}54 \text { patients with } \\
\text { aphasia }\end{array}$ & $\begin{array}{l}\text { Evaluate the relationship } \\
\text { between the extent } \\
\text { of brain lesions and } \\
\text { performance of the } \\
\text { subjects on dichotic } \\
\text { listening tests; } \\
\text { Check the validity of the } \\
\text { application of these tests } \\
\text { to define commitment in } \\
\text { the Heschl gyrus; }\end{array}$ & $\begin{array}{l}\text { Audiological evaluation of } \\
\text { freq. } 500,1000 \text { and } 2000 \\
\mathrm{~Hz} \text {, dichotic digits test and } \\
\text { computed tomography }\end{array}$ & $\begin{array}{l}\text { The results obtained } \\
\text { with dichotic digits } \\
\text { test showed a positive } \\
\text { correlation to determine } \\
\text { the involvement or not of } \\
\text { of Heschl's gyrus in cases } \\
\text { of aphasia }\end{array}$ \\
\hline $\begin{array}{l}\text { Niccum et al, } \\
1986 \text { (B) }\end{array}$ & $\begin{array}{l}54 \text { patients with } \\
\text { aphasia }\end{array}$ & $\begin{array}{l}\text { Analyze if occurs } \\
\text { change in hemispheric } \\
\text { dominance for language; } \\
\text { Verify the relationship } \\
\text { between ear advantage } \\
\text { and performance on } \\
\text { language tests; }\end{array}$ & $\begin{array}{l}\text { Audiological evaluation of } \\
\text { freq. } 500,1000 \text { and } 2000 \\
\mathrm{~Hz} \text {, dichotic digits test } \\
\text { and application of specific } \\
\text { language tests. }\end{array}$ & $\begin{array}{l}\text { There was no greater } \\
\text { tendency to left ear } \\
\text { advantage (LEA) and } \\
\text { the right hemisphere } \\
\text { dominance for language } \\
\text { in patients with aphasia. }\end{array}$ \\
\hline Shisler (2005) & $\begin{array}{l}06 \text { subjects with } \\
\text { aphasia and } 06 \\
\text { subjects from a } \\
\text { control group }\end{array}$ & $\begin{array}{l}\text { Check if the auditory } \\
\text { extinction is present in } \\
\text { individuals with aphasia; } \\
\text { Investigate whether } \\
\text { auditory extinction } \\
\text { occurs due to a deficit in } \\
\text { integration (binding); }\end{array}$ & $\begin{array}{l}\text { Application of Boston } \\
\text { test, evaluation of the } \\
\text { understanding of complex } \\
\text { orders, DSS presentation } \\
\text { of stimuli (letters "T" } \\
\text { and "O") and a task with } \\
\text { numbers; }\end{array}$ & $\begin{array}{l}\text { Auditory extinction } \\
\text { occurred in all volunteers } \\
\text { of the group with aphasia, } \\
\text { there is evidence that } \\
\text { integration (binding) } \\
\text { influences the listening } \\
\text { comprehension; }\end{array}$ \\
\hline $\begin{array}{l}\text { Ortiz; Peroni } \\
(2008)\end{array}$ & $\begin{array}{l}20 \text { subjects with } \\
\text { aphasia and } 20 \\
\text { subjects from a } \\
\text { control group }\end{array}$ & $\begin{array}{l}\text { Assess the following } \\
\text { auditory abilities: figure- } \\
\text { ground and auditory } \\
\text { selective attention; }\end{array}$ & $\begin{array}{l}\text { Audiological evaluation of } \\
\text { freq. } 500,1000 \text { and } 2000 \\
\mathrm{~Hz}, \mathrm{SRT}, \mathrm{M} 1-\mathrm{Alpha} \text { test, } \\
\text { impedance and PSI }\end{array}$ & $\begin{array}{l}\text { Individuals with aphasia } \\
\text { demonstrated impairment } \\
\text { in activities that required } \\
\text { the auditory abilities of } \\
\text { figure and ground and } \\
\text { selective attention; }\end{array}$ \\
\hline
\end{tabular}




\section{RESUMO}

A avaliação do Processamento Auditivo (PA) é um procedimento audiológico que fornece informações importantes relacionadas ao processo de compreensão do material linguístico. Com o objetivo de investigar as pesquisas que abordam a interface PA - Afasia foi realizada uma revisão sistemática tomando por referência os seguintes descritores e seus correlatos em língua inglesa: Afasia, Dicótico, Monótico, Processamento auditivo e Habilidades auditivas; a busca foi realizada no formato intersecção com o conectivo and. Os cinco estudos incluídos nesta pesquisa diferem em aspectos diversos nos seus objetivos, tais como localização da lesão, mudança da dominância hemisférica para linguagem, presença de vantagem da orelha esquerda em quadros de afasia, relação entre habilidades auditivas e linguagem e a extinção auditiva. Os trabalhos analisados sugerem que as abordagens acerca do processamento auditivo e afasia ocorreram sob duas perspectivas de funcionamento cortical: teoria localizacionista e teoria distribucionista, estando a maioria dos artigos (três), em consonância com a primeira corrente (localizacionista).

DESCRITORES: Afasia; Audição; Fonoaudiologia

\section{REFERENCES}

1. Zeigelboim BS, Klagenberg KF, Liberalesso PBN, Menezes P, Gonçalves DV. Avaliação neurofisiológica das vias auditivas e do equilíbrio na afasia de Broca - Apresentação de um caso ilustrativo. Journal of Epilepsy and Clinical Neurophysiology. 2010;16(4):143-8.

2. Sitta El, Arakawa AM, Caldana ML, Peres SHCS. A contribuição de estudos transversais na área da linguagem com enfoque em afasia. Rev. CEFAC. 2010; 12(6):1059-66.

3. Albuquerque AG, Costa MLG, Sena EFC, Luz LMS. Análise da produção de sentidos em narrativas de afásicos participantes de grupo de convivência. Rev. CEFAC. 2010;12(1):51-6.

4.Quintas VG, Attoni TM, Keske-Soares M, Mezzomo CL. O processamento auditivo e a combinação de traços distintivos na aquisição de fala em crianças com desvios fonológicos. Rev. Soc. Bras. Fonoaudiol. 2011;16(2):167-73.

5. Pelitero TM, Manfredi AKS, Schneck APC. Avaliação das habilidades auditivas em crianças com alterações de aprendizagem. Rev. CEFAC. 2010; 12(4):662-70.

6. Cochrane de Revisões Sistemáticas. [acesso em ago 2011]. Disponível em: http:cochrane.bireme. $\mathrm{br} /$ portal/php/level.php?lang=pt\&component=19 \&item $=11$

7. Sampaio RF, Mancini MC. Estudos de Revisão Sistemática: Um guia para síntese criteriosa da evidência científica. Rev. Bras. Fisioter. 2007;11(1):84-9.

8. Coury HJCG, Moreira RFC, Dias NB. Efetividade do exercício físico em ambiente ocupacional para controle da dor cervical, lombar e do ombro: uma revisão sistemática. Rev. Bras. Fisioter. 2009;13(6):461-79.

9. Niccum N. Longitudinal Dichotic Listening Patterns for Aphasic Patients. I Description for recovery curves. Brain and Language. 1986;28:273-88.

10. Niccum N, Speaks C, Rubens AB, Knopman DS, Yock D, Larson D. Longitudinal Dichotic Listening Patterns for Aphasic Patients. II Relationship with lesion variables. Brain and Language. 1986;28: 289-302.

11. Niccum N, Selnes OA, Speaks C, Risse GL, Rubens AB. Longitudinal Dichotic Listening Patterns for Aphasic Patients. III Relationship to language and memory variables. Brain and Language. 1986;28:303-17.

12. Ortiz KZ, Peroni C. Compreensão de fala em situação de mensagem competitiva em afásicos. Rev. CEFAC. 2008;2:226-32.

13. Shisler RJ. Aphasia and auditory extinction: Preliminary evidence of binding. Aphasiology. 2005;19(7):633-50.

14. Pereira LD, Schochat E. Processamento auditivo central: manual de avaliação. São Paulo: Lovise; 1997. p. 100-49

15. Bamiou DE, Werring D, Cox K, Stevens J, Musiek FE, Brown MM et al. Patient-reported auditory functions after stroke of the central auditory pathway. Stroke. 2012;43(5):1285-9.

16. Niccum N, Rubens AB. "Late" recovery of the right ear dichotic score following cerebrovascular accident: a case report. Neuropsychologia. 1983;21(6):699-704.

17. Marshall RS, Garcia-Barrera M, Yanosky II D. An exploratory study of auditory extinction in ageing: 
642 Nascimento MSR, Muniz LF, Costa MLG

Now your hear it, now you don't. Aphasiology. 2008;23(1):72-86.

18. Nicolelis M. Muito além do nosso eu: a nova neurociência que une cérebro e máquinas - e como ela pode mudar nossas vidas. São Paulo: Companhia das Letras. p. 17-21.
19.Lebedev MA et al. Future developments in brainmachine interface research. Clinics (São Paulo). 2011;66(S1):25-32.

20. Vieira ACC, Roazzi A, Queiroga BM, Asfora, R, Valença MM. Afasias e áreas cerebrais: argumentos prós e contras à perspectiva localizacionista. Psicologia: Reflexão e Crítica. 2011;24(3):588-96.

Received on: March 06, 2012

Accepted on: June 23, 2012

Mailing address:

Maria da Soledade Rolim do Nascimento

Rua Fortaleza, 55, Jardim Brasil II

Olinda - PE

CEP 53290-250

E-mail: soledade_nascimento@yahoo.com.br

Rev. CEFAC. 2014 Mar-Abr; 16(2):634-642 